[Vo1. 101

\title{
NOTES
}

\section{COMPETITION IN GASOLINE RETAILING: A PRICE WAR}

The price war in gasoline retailing is not an innovation; however, the increase in the number of automobile owners, the growth of strong retail dealer associations, and the recent nationwide recurrence of gasoline price wars in metropolitan areas have served to arouse a greater public interest in this phenomenon. The purpose of this Note is to consider the economic and social causes of a particular, and presumably typical, gasoline price war in the Philadelphia-Camden area; the legal consequences involved in initiation, aggravation and termination of the price war; and methods used to prevent future price wars, including the desirability of legislation directed toward that end.

\section{A Case Study ${ }^{1}$}

In 1949 a Philadelphia retail dealer ${ }^{2}(A)$ of Esso gasoline was competing with other dealers in the same and other branded ${ }^{3}$ gasolines. The price of regular ${ }^{*}$ gasoline for all brands in the area remained relatively constant at 26.9 cents a gallon. To compete for customers, $A$ endeavored to make his station as attractive as possible; he also furnished extra services cheerfully, and offered "specials" on accessories. He and the other dealers were operating at what they considered to be a "fair" margin, usually explained in terms of overhead costs and family living expenses. At the time, this margin amounted to 5.2 cents a gallon, which was generally considered "fair."

Early in 1950 a modern multi-pump station was constructed in the neighborhood by Saveway, a retailing chain that vended non-branded ${ }^{5}$ gasoline. The Saveway station provided none of the free tire, battery, and windshield services offered by the Esso dealer, but began selling its gasoline

1. This case study is based upon interviews with representative dealers and refiners in the Philadelphia-Camden area.

2. The retail level of the industry is characterized by three types of service stations where branded gasoline is being sold:

(a) Employee-operated-where the retailer is employed by the supplier who owns and operates the station.

(b) Lessee-operated-where the retailer is a lessee of the supplier, paying a flat rental for the station and/or a graduated rental based on gallonage.

(c) Owner-operated-where the retailer owns the station and contracts with the supplier for his products.

3. A "branded dealer" retails gasoline under the brand name of his supplier.

4. This Note is concerned only with the price of regular gasoline as opposed to hi-test which sells for more and has a higher octane rating.

5. A "non-branded dealer" does not market his gasoline under the brand name of his supplier. 
at 22.9 cents a gallon. The Esso dealer along with other dealers in advertised brands soon learned that large numbers of their former customers were more interested in price than in brand, especially since car performance indicated that the new station was not selling inferior quality gasoline. Apparently, the public also had little interest in the extra services furnished by the branded dealers, when they realized that these services were reflected in a price differential of four cents a gallon.

With their gallonage ${ }^{6}$ decreasing rapidly, as much as $50 \%$ in several reported instances, the dealers and suppliers ${ }^{7}$ of branded gasoline in the area began to take steps to meet the new price competition. Sun Oil Company, for instance, sent salesmen to its neighboring outlets advising the dealers to cut their price to 24.9 cents a gallon. The Sun management believed that a branded gasoline could effectively compete with a nonbranded gasoline which sold for only one to two cents less. Sun dealers adopted their supplier's suggestion, and soon other branded dealers, including the Esso dealer, were cutting their prices to this level.

A neighboring Esso dealer $(B)$ had recently converted his station into a modern multi-pump emporium complete with all extra services. $\mathrm{He}$ very quickly felt the effect of the 22.9 cents price of his new competitor. To save his business investment $B$ decided he would have to meet Saveway at its own price. Counting on the greater consumer response to branded gasoline, he conspicuously displayed his reduced price by placing a large sign in front of his station. Simultaneously he eliminated services, including repairs, ${ }^{8}$ requiring skilled, higher paid employees, and thereby transformed his business into a gas pumping enterprise which could be handled by cheap labor. His gallonage consequently increased tenfold to the point that gasoline was being dispensed almost as rapidly as Esso could supply it. Although his margin was only 1.2 cents a gallon above Esso's tankwagon price ${ }^{9}$ of 21.7 cents, $B$ was making about three times as much as before the "war."

Dealer $B$ 's competitive response to the appearance of Saveway diminished Dealer $A$ 's gallonage even further. $A$ and other affected Esso outlets grudgingly reduced their prices to 23.9 cents, still one cent above $B$ 's (and Saveway's) price; however, unable to match $B$ 's low overhead, they continued to suffer losses. They complained vigorously to the Esso Sales office about $B$ 's underpricing. Under pressure of the complaints, Esso's district sales manager attempted to persuade $B$ to raise his price. The district

6. The gallonage of the average retailer in this area is ten to twelve thousand gallons a month.

7. The term "supplier" in this note refers to the refiner of crude oil. In the Philadelphia and Camden areas the great bulk of the gasoline supplied to retail outlets is distributed by the refiner.

8. New engineering advances in automobile manufacturing have resulted in fewer service requirements.

9. The "tank-wagon price" is the price paid by the retail dealer. Normally, the tank-wagon price is the same for all branded gasoline, regardless of the supplier and the method of distribution to the retail outlet. See discussion of "price leadership," infra. 
manager pointed out that Saveway handled an inferior gasoline and $B$ could charge a higher price and still be competitive. $B$ countered that it was an open secret in the industry that a large branded gasoline company or companies were supplying Saveway under a contract providing for a price substantially less than that paid by the branded outlets. He reinforced his argument by illustrating that the Saveway advertisements were couched in such terms as to indicate that Saveway gasoline was just as good as any regular branded gasoline. It became apparent to the district manager that $B$, who had of late become a successful entrepreneur, was in no negotiating mood. With a few well chosen words to indicate that such matters of cooperation were considered when the time for renewal of contracts for gasoline and oil came around, the district manager left the busy premises.

Sun Oil reacted to similar dealer complaints by granting to its outlets in areas it deemed critically affected temporary competitive allowances in the form of guaranteed margins of 3.5 cents a gallon. Other suppliers adopted similar subsidizing practices, including reduction of tank wagon price and/or rent to affected dealers, so that branded dealers were able to bring and keep their retail prices within one cent of Saveway's ever plummeting price which reached a nadir of 13.9 cents by fall of 1950 . All the while dealer $B$, who was now buttressed by Esso's allowance, had met each Saveway cut with an identical price cut.

In addition to complaining to their suppliers, the branded dealers combined among themselves in an attempt to forestall the price war, largely by appealing for remedial legislation. In Philadelphia, they succeeded in having an ordinance adopted by the City Council ${ }^{10}$ limiting the size of signs at the stations advertising the price of gasoline. However, late in 1950 a dissenting group of dealers, led by $B$, contested the constitutionality of the ordinance, as a result of which its enforcement was stayed. ${ }^{11}$ In adjoining Camden, where a price war had started soon after Saveway established another station there, the dealers' association caused the Governor of New Jersey to appoint a special investigating committee. ${ }^{12}$ The New Jersey dealers also allowed themselves to be organized by the Teamsters' union. ${ }^{13}$ The purpose of this affiliation was apparently to obtain the cooperation of the teamsters in an effort to cut off the supply of gasoline to price-cutters. In the summer of 1951 those stations which displayed signs advertising cut prices were picketed by dealers carrying signs bearing the words "Unfair to Organized Labor." Motorists refused to respect the picket lines, however, and because of threatened legal action by the Sun Oil

10. Journal of City Council of Philadelphia, Appendix §273, Oct. 5, 1950.

11. Subsequently the ordinance was held constitutional. Mark Robbins v. City of Philadelphia, Pa. C.P. 6, March 1, 1951. However, operation of this ordinance has been stayed pending an appeal to the Supreme Court of Pennsylvania.

12. See Rep., Gasoline Study Comm. of N.J. (1951).

13. United Service Station Operators' and Employees' Union organized by the International Brotherhood of Teamsters, Chauffeurs, Warehousemen and Helpers, Local No. 676, affiliated with the American Federation of Labor. 
Company the picket lines were removed. ${ }^{14}$ Eventually the New Jersey legislature passed a statute limiting the size of gasoline price signs which remains uncontested. ${ }^{15}$

Prices had unevenly crept upward from the low point reached in the fall of 1950 , partly because of gradually decreasing subsidies by suppliers and partly because of dealer agreements aimed at raising prices. Late in February of 1952, when the competitive allowance amounted to approximately 3 to 4 cents a gallon, all the suppliers discontinued the subsidy practice within a few days of each other. Tank-wagon prices returned to and have since remained at the pre-price-war level of 21.7 cents a gallon in Philadelphia and 19.6 cents in Camden (the New Jersey tax being two cents below Pennsylvania's)..$^{18}$ In Camden, because of the New Jersey statute, "circus" signs have been removed by the dealers and placed in the back rooms of stations in apparent readiness for the next fight for gallonage. Many dealers at first decided to charge 25.4 cents (OPS ceiling at that time) because there was now no fear of a price-cutter catching the eye of a price-conscious motorist. However, since Saveway has continued to charge 22.9 cents, many Sun dealers have refused to go higher than 24.9 cents. Accordingly, all branded dealers felt compelled to bring their prices down 0.5 cents, from the 25.4 cent level, in order to meet competition. The price to the consumer in the Camden area has remained stable at this point.

In Philadelphia, the price war has continued in certain sections. With the sign ordinance enjoined, signs inviting motorists to take advantage of lower prices are still displayed. The average price of branded gasoline in affected areas is 23.9 cents. Saveway and $B$, who is now selling Richfield gasoline, apparently as a result of his failure to raise prices at the further request of the Esso district manager, are charging 22.9 cents. However, where the influence of Saveway and price-cutters is not felt as keenly, the public is paying from 26.9 to 28.9 cents per gallon for gasoline. This perplexing situation has once again had state-wide ramifications. As late as August, 1952, factions of retail dealers appealed to the Governor for a probe of the retail gasoline business in Pennsylvania. The findings were to be utilized to formulate future legislation. ${ }^{17}$ It was suggested that the intense price competition had forced many "honest" dealers to carry on tion.

14. At present many dealers still are dues-paying members of the labor organiza-

15. N.J. Stat. ANN. 56:6-2.2 (Supp. 1952), which became effective May 22, 1952. The statute provides that the price sign may not exceed $8 \times 10$ inches and must be on the pump only.

16. Dwight T. Colley, Vice-President of Atlantic Refining Co., in an address to the Pennsylvania Petroleum Association urged major suppliers not to indulge in practices which promote gasoline price wars and keep them going at the retail level. Gasoline Retailer, May 21, 1952, p. 9, col. 1.

17. "We are convinced that the Commonwealth should take matters into its own hands as far as the gasoline retailers in the commonwealth of Pennsylvania are concerned." Petition of Gasoline Retailers Association presented to the Governor of Pennsylvania by Gerald W. Ulman, General Counsel. Philadelphia Inquirer, August 12, 1952, p. 7, col. 5. Query whether this would include a special commission to be set up for the purpose of controlling entrance into gasoline retailing as well as regulating methods of competition. 
fraudulent practices in retailing their gasoline, and that this would continue so long as a few men insisted on making gasoline retailing a "pumping" business. However, to date no state action has been taken to change matters. ${ }^{18}$

\section{Legal Consequences}

\section{Initiation}

Members of the industry suggest that Saveway is supplied under a long-term contract by a major supplier which also supplies its own branded outlets in this area. Is a differential in price granted by such a supplier between these two outlets a prohibited discrimination within the meaning of the Robinson-Patman Act? It has been said that when the national brand is removed, the difference in price is not discriminatory since a different and inferior product in the economic sense is being sold. ${ }^{19}$ However, the Act makes no such exception. The Act makes it ". . . unlawful . . to discriminate in price between different purchasers of commodities of like grade and quality ... . where the effect of such discrimination may be substantially to lessen competition . . . or to injure, destroy, or prevent competition with any person who... knowingly receives the benefit of such discrimination. . . " 20 If the gasoline supplied to the branded and non-branded dealers is of "like grade and quality," any discrimination in price puts the burden of showing justification, to rebut the prima facie case thus made, upon the person charged with the violation. ${ }^{21}$ The Act provides that nothing contained therein ". . . shall prevent differentials which make only due allowance for differences in the cost of manufacture, sale, or delivery resulting from the differing methods or quantities in which such commodities are to such purchasers sold or delivered." 22 In selling non-branded gasoline to a single purchaser, the

18. Contrary to the picture as painted above, some dealers think that price wars are instigated by a major supplier persuading its retail outlets to decrease their prices. This would temporarily serve to increase the gallonage of both retailer and supplier and to relieve storage problems of the supplier which finds itself in possession of more refined product than its existing storage facilities will hold. However, such a theory was found, during this study, to have no basis in fact in the PhiladelphiaCamden area. It also seems theoretically unsound because the industry must realize that the benefit which would accrue to the supplier initiating such a price war would be only temporary. In the long run, profits would decline, since it is doubtful that consumer purchase of gasoline increases substantially during a price war, but it is definite that cost to the consumer declines. Furthermore, the accuracy of the individual suppliers in allocating production makes such a theory even more suspect.

19. Dirlam and Kahn, Leadership and Conflict in the Pricing of Gasoline, 61 YALE L.J. 818, 833 n.48 (1952).

20. 38 StAт. 730 (1914), as amended, 15 U.S.C. $\$ 13$ (1946).

21. Samuel H. Moss, Inc. v. FTC, 148, 378 (2d Cir. 1945) ; Cf. FTC v. Morton Salt Co., 334 U.S. 37 (1948), where the Court first states (at 44) that a discrimination in price violated the Act if it had the defined effect on competition and then (at 50) declares it to be "self evident" that competition may be adversely affected when a producer sells his goods to some customers at a price substantially less than to competitors of such customers. See FTC v. A. E. Staley Mfg. Co., 324 U.S. 746, 760 (1945); Ruberoid Co. v. FTC, 189 F.2d 893 (2d Cir. 1951).

22. See note 20 supra. 
supplier usually will realize substantial savings in selling and distribution costs which can be reflected in the price sold. For example, none of the supplier's costs of advertising his own brands will be allocable to nonbranded gasoline. But whether the differential is such as to make only "due allowance" requires the consideration of facts not now available. Even if the gasoline supplied to the non-brand dealers is not of "like grade and quality" with that supplied to the brand dealers, but is competitive with it, and sold for the purpose of eliminating competition, at a price so low as to be disproportionate to the difference in quality, there may be an unfair method of competition prohibited by the Federal Trade Commission Act. ${ }^{23}$

\section{Aggravation}

Some dealers faced with financial losses and possibility of insolvency because of the price war appeal to their suppliers for relief, as $A$ did in the case study. The supplier's decision as to whether to grant or withhold a price concession to a particular dealer is complicated by conflicts in its interests. While wishing to relieve its outlet, it still desires to inhibit the spread of the price war. The usual supplier solution is to designate a specific territory as a "critical area" in which a uniform competitive allowance in the wholesale price of gasoline is made to dealers. Two reported instances have pointed up the arbitrary character of this solution. In one case $X$ owned a station on a main highway just outside the city limits of Philadelphia. $Y$, who sold the same product, owned a similar station on the same highway just inside the city line. Their supplier considered the city line as the boundary of the "critical area" and gave an allowance only to those within the city. In this instance $X$ could not successfully compete with $Y$. In another case $Z$ owned a station on a main thoroughfare which fell within the "critical area" as drawn by his supplier. Price wars flourished on adjoining streets, but no competing station was located on $Z$ 's thoroughfare for some distance on either side of his station. As a result $Z$ felt little competitive pressure to lower his price, so that the supplier's concession to increased competition in the area was not passed on to $Z$ 's customers.

Such discrimination by a supplier engaged in interstate commerce is a prima facie violation of the Robinson-Patman Act. ${ }^{24}$ However, a supplier may justify this practice by showing that its lower price to any purchaser "was made in good faith to meet an equally low price of a competitor." 25 It must prove the existence of facts which would lead a reasonable and prudent person to believe that the granting of a lower price would in fact meet the equally low price of a competitor. ${ }^{26}$ Such lower price must not undercut the competitor's price, ${ }^{27}$ and if the competitor's goods normally

23. See Austin, Price Discrmmination 40 (1952).

24. See note 21 supra.

25. See note 20 supra.

26. FTC v. A. E. Staley Mfg. Co., 324 U.S. 746 (1945).

27. Samuel H. Moss, Inc. v. FTC, 148 F.2d 378, 379 (2d Cir. 1945). 
sell at a lower price (as in the case of lower grade or unadvertised brands) a mere meeting of such price may be held to be lacking in "good faith" since meeting such a price is unnecessary to meet the competition. ${ }^{28}$ Perhaps it must prove that its lower price was not made for the purpose of eliminating or injuring a competitor. ${ }^{29}$ Is this process of designating "critical areas" as illustrated by the above examples a "good faith" meeting of competition? The primary remedial objective of the Act is to suppress discriminations, between customers of the same seller, not supported by sound economic differences in their business positions or in the cost of serving them. ${ }^{30}$ The Act thus places emphasis on individual competitive situations. $^{31}$ Therefore, although the dealer allowances are ordinarily temporary ${ }^{32}$ and the supplier has an economic stake in halting the price war, a practice of drawing arbitrary lines to separate those in the affected area probably would not meet the requirement of a "good faith" meeting of competition. However, it would seem that the supplier should have some reasonable measure of discretion in determining exactly what are the boundaries of the "critical area," and if he can demonstrate his good faith in this determination, he should not be held to have violated the Act.

It is interesting to note that since March 1952, no competitive allowance has been openly granted to dealers in the Philadelphia-Camden area. Although the price war had substantially abated by then, this policy decision on the part of suppliers also might be due to the Robinson-Patman implications discussed above.

\section{Termination by Dealer Control}

Trade Association Activities.-Recent years have witnessed the organization of dealers into associations to promote their mutual interests. Membership in these organizations increases during a price war and decreases during periods of stable prices. One of the main purposes of these organizations is to keep the retail prices of gasoline stable. ${ }^{33}$ Methods to effectuate this goal include appeals to the legislature and agreements among the members not to engage in price cutting activities. ${ }^{34}$ Even though this is a 1929).

28. Porto Rican Tobacco Co. v. American Tobacco Co., 30 F.2d 234 (2d Cir.

29. See Austin, Price Discrimination 97 (1952).

30. H.R. Rep. No. 2951, 74th Cong., 2d Sess. (1936).

31. See FTC v. Cement Institute, 333 U.S. 683, 725 (1948).

32. Cf. Ibid., where the Court said that the good faith meeting of competition proviso did not permit a seller to use a sales system which constantly resulted in his getting more money for like goods from some customers than from others.

33. James V. Cresente, President of the Cleveland Independent Dealers Association, concluded a report on a survey of service stations as follows: "Do like other small businessmen have done. When they found that they were working too long for too little, they banded together and formed a businessmen's association. They solved their own problems by maintaining regular business hours and establishing a profitable mark-up for their wares." Gasoline Retailer, June 18, 1952, p. 9, col. 1 .

34. See The Philadelphia Evening Bulletin, Feb. 27, 1953, p. 3, col. 4, where a dealer admits that such agreements have been made. For another type of price agreement, see note 69 , infra. 
local association, such agreements establishing margins would probably be a violation of the Sherman Act. ${ }^{35}$ The primary purpose of stabilizing the price of gasoline in the market area, i.e., the city and suburban areas in the case study, makes the agreement illegal per se whether or not the parties to the agreement have the power, through substantial market control, $^{36}$ to effectuate that purpose. ${ }^{37}$

On several occasions dealers have been known to form small cliques and attempt to stop price-cutting activities by directly coercing the pricecutter through threats and intimidation, or by indirectly exerting pressure on him through annoying practices of doubtful legality. For example, "motorists" have driven their cars into price-cutting stations at the peak of the business day and, after ordering one gallon of gasoline, tendered large bills in payment. Traffic jams produced by the ensuing delay soon discouraged many waiting drivers who moved on to other stations. Attempts have also been made by dealers to purchase all the price-cutter's gasoline at the low price. Such competitive practices may be tortious, and injunctive relief and/or damages might be obtained under applicable state law..$^{38}$

Labor Union Activity. - In the case study the Camden dealers' association took the form of a "union" whose members were predominantly owners and lessees of stations, as well as some employees. There was no semblance of a collective bargaining purpose and no employer with whom to bargain; yet apparently the group considered itself a "labor union." It engaged in organized picketing of dealers who displayed signs advertising lower prices. The announced purpose of the picketing was organizational: to force price-cutting dealers to join the union, whose rules proscribed such signs. But, as indicated above, the ultimate purpose of the organization was to stabilize gasoline prices in the area.

Such a union should not qualify for the rights of a "labor organization" under the National Labor Relations Act, ${ }^{39}$ which contemplates an organization of employees existing for the purpose of bargaining with employers concerning grievances, wages, rates of pay, hours of employment or condi-

35. 26 STAT. 209 (1890), 15 U.S.C. $\$ 1$ (1946). Where local association activity is scrutinized, it is questionable whether the interstate commerce requirement is met; however, in view of the interstate character of gasoline distribution any price agreement at the retail level as to gasoline would probably be held to affect the flow of commerce. See Mandeville Island Farms, Inc. v. American Crystal Sugar Co., 334 U.S. 219 (1948); United States v. Gimbel Bros., CCH '48-'51 TRADE REG. SERv. If 61,244 (1950). But cf. Spencer v. Sun Oil Co., 94 F. Supp. 408, 415 (D. Conn. 1950) where the court said: "An agreement to maintain existing gasoline retail prices entered into by retailers of gasoline in the Meriden area, is an agreement not in interstate commerce, but is in violation of the common law of Connecticut."

36. Cf. United States v. Trenton Potteries, 273 U.S. 392 (1927).

37. United States v. Socony-Vacuum Oil Co., 310 U.S. 150 (1940). But cf. Appalachian Coals, Inc. v. United States, 288 U.S. 344 (1933).

38. See Prosser, Torts, $\$ 105$ (1941), and cases cited therein.

39. 49 STAT. 4491 (1925), 29 U.S.C. \$151 et seq. (1946), as amended, 61 Stat. 1361 (1947), 29 U.S.C. \$141 et seq. (Supp. 1949). 
tions of work. ${ }^{40}$ Protection under the Act has been extended in several instances to persons traditionally considered entrepreneurs where they have been affected by the mischief aimed at by the Act. ${ }^{41}$ Included have been taxi drivers, ${ }^{42}$ red-cap porters, ${ }^{43}$ seamstresses, ${ }^{44}$ insurance canvassers ${ }^{45}$ and newsboys. ${ }^{46}$ Since labor is not a commodity in interstate commerce because of $\S 6$ of the Clayton Act, ${ }^{47}$ an ancillary effect of allowing such groups to organize has been to exclude them from prosecution for monopolization under the Sherman Act. The exemption, at first construed very narrowly, was extended by the passage of the Norris-LaGuardia Act ${ }^{48}$ by curtailing drastically the equity jurisdiction of federal courts in the field of labor disputes even where a violation of the Sherman Act is alleged because of concerted action on the part of the union. ${ }^{49}$ The purpose of exempting labor groups from the anti-trust laws was to allow people in inferior bargaining positions, because of their lack of resources as compared with employers, to organize and act without fear of violating the law. ${ }^{49 a}$ It would appear, therefore, that the aforementioned "independent contractors"newsboys, porters, etc.-should be allowed such power since such groups are in an inferior bargaining position in regard to the buyers of their labor. However, in two recent pronouncements courts seem to have lost sight of this underlying policy; ruling that the exemption will not apply unless an employer-employee relationship is the matrix of the controversy, ${ }^{50}$ and further, that a dispute as to the price of a commodity does not fall within the scope of the exempting acts.51 Under these decisions, the "union" of retail gasoline dealers which attempted to stabilize prices would certainly not be protected from injunction by the Norris-LaGuardia Act, or the state counterparts thereof, ${ }^{62}$ since there was no employment situation in-

40. The term "labor organization" means any organization of any kind, or any agency or employee representative committee or plan, in which employees participate and which exists for this purpose, in whole or in part, of dealing with employers concerning grievances, labor disputes, wages, rates of pay, hours of employment, or conditions of work. 61 STAT. 138 (1947), 29 U.S.C. \$152 (5) (Supp. 1949).

41. See NLRB v. Hearst Publications, Inc., 322 U.S. 111 (1944).

42. Taxi-Cab Drivers Local Union No. 899 v. Yellow Cab Operating Co., 123 F.2d 262 (10th Cir. 1941).

43. Williams v. Jacksonville Terminal Co., 315 U.S. 386 (1942).

44. United States v. Vogue, 145 F.2d 609 (4th Cir. 1945).

45. Ia Lone v. United States, 57 F. Supp. 947 (D. Wash. 1944).

46. NLRB v. Hearst Publications, Inc., 322 U.S. 111 (1944).

47. 38 STAT. 731 (1914), 15 U.S.C. \$17 (1946).

48. 47 STAT. 70 (1932), 29 U.S.C. $\$ 101$ (1946).

49. Milk Wagon Drivers' Union v. Lake Valley Farm Products, 311 U.S. 91 (1940); United States v. Hutcheson, 312 U.S. 219 (1941).

49a. See Gottesman, Restraint of Trade-Employees or Enterprisers? $15 \mathrm{U}$. OF CFI. L. REv. 638 (1948).

50. Columbia River Packers Assoc. v. Hinton, 315 U.S. 143 (1942); Ring v. Spina, 148 F.2d 647 (2d Cir. 1945).

51. Hawaiian Tuna Packers, Ltd. v. International Longshoremen's Union, 72 F. Supp. 562 (D. Hawaii 1947) (alternative holding).

52. Such statutes were patterned after the federal Norris-LaGuardia Act. See, e.g., N.J. STAT. ANN. \& 2:29-77.1 et seq. (Supp. 1951).

The state statutes differ from the Norris-LaGuardia Act which expressiy provides that the employer-employee relationship need not exist between the disputants. 47 STAT. 73 (1932), 29 U.S.C. $\$ 113$ (c) (1946). The following language is usually 
volved. Furthermore, the fact that the retailers were not organizing with the object of equalizing their bargaining position as to those with whom they deal-in this situation the general public-would indicate that they should be given no protection under statutes benefiting labor. Here we have bargaining in its simplest form-retailers dealing at arms length with the public. Each group may buy or sell as it wishes and there is no compelling argument that either one has an inferior bargaining position. The organization of retailers, with the concomitant result of price-fixing, would indeed upset that equilibrium of bargaining power and should be condemned both doctrinally and policywise.

Constitutional protection of peaceful picketing ${ }^{53}$ would probably be no obstacle to the party seeking an injunction in a state court since state policy against the purpose for which the picketing is being carried on, legislatively or judicially declared, would be sufficient to overcome constitutional objections. ${ }^{54}$

\section{Termination by Supplier Control}

The retailer's situation in the gasoline industry is different from that of the average merchant. His whole business is built around pumps and tanks which can be used only for his supplier's gasoline. ${ }^{55}$ In many cases he is a lessee who pays rent to the supplier. It would be unrealistic to call him completely independent. ${ }^{56}$ As a practical matter he cannot try Atlantic one month and Gulf the next. $\mathrm{He}$ is told to associate himself with the product he sells. Above all he is told that friendly service, attractive stations, ${ }^{57}$ sanitary rest rooms, and good locations are the competitive weapons to emphasize.

found in state court decisions construing their anti-injunction acts. "The act is bottomed in the employer and employee relationship, . . . and the phrase "labor dispute' as defined and used in the act necessarily must be founded upon or proximately grow out of a basic relationship of employer and employee and a dispute concerning terms or conditions of employment." Outdoor Sports Corp. v. Local 23132, A.F. of L., 6 N.J. 217, 227, 78 A.2d 69,74 (1951).

53. See Thornhill v. Alabama, 310 U.S. 88 (1940).

54. See Giboney v. Empire Storage \& Ice Co., 336 U.S. 490 (1949) (antitrust legislative policy); Building Service Employees International Union, Local $262 \mathrm{v}$. Gazzam, 339 U.S. 532 (1950) (public policy of state as announced by legislature in regard to state labor legislation); International Brotherhood of Teamsters, Local 309 v. Hanke, 339 U.S. 470 (1950) (judicially announced policy of "rugged individualism").

55. This practice was held not to be a violation of $\$ 3$ of the Clayton Act, 38 STAT. 731 (1914), 15 U.S.C. \$ 14 (1946), which outlaws tying clauses "where the effect may be to substantially lessen competition." FTC v. Sinclair Refining Co., 261 U.S. 463 (1923).

56. Although the dealer claims that he can get batteries, tires and accessories from anyone, it is usually from someone whom the supplier suggests. The retailer rationalizes this practice by saying that it is good business to deal with a dependable firm, and suppliers will usually recommend a reliable outfit. Such conduct is questionable in the light of recent decisions. See Standard Oil of California v. United States, 337 U.S. 293 (1949) ; United States v. Richfield Oil Corp., 99 F. Supp. 280 (S.D. Cal. 1951), aff'd, 343 U.S. 922 (1952). The government is now in the process of litigating these arrangements. See United States v. Sun Oil Co., Civil No. 10483, E.D. Pa., Jan. 12, 1950.

57. For an entertaining description of the increase in the number of attractive service stations see an excerpt from an address delivered by Harold L. Ickes, when 
During a price war many retailers who have been emphasizing service continue to do so. Under such conditions they cannot hope to run their stations as economically as the price-cutter. Rather than advocate that non-price-cutters stop emphasizing service, some suppliers attempt to influence the price-cutter to restore his price to "normal." 58 If such pressure is successful, the price war will come to a speedy end and many of the supplier's outlets will be relieved. Since it is the seller's prerogative to stipulate his conditions of sale, such persuasion, including cutting off an uncooperative retailer, does not constitute a violation of the antitrust laws.59 But, in view of the interstate character of gasoline distribution, an agreement between a dealer and a supplier as to the retail price to be charged in the sale of gasoline already sold to the dealer might violate the Sherman Act. $^{60}$ However, the Miller-Tydings amendment ${ }^{61}$ does permit a supplier, as an incident of his contract of sale, to indicate concurrently the resale price in a state which has enacted fair trade legislation. ${ }^{62}$ This has not been done in the Philadelphia-Camden area.

Where supplier influence fails, the supplier begins to make competitive allowances. As the price war continues, the supplier's gallonage soon approximates that of before the "war," but at diminished profits, or even losses. ${ }^{63}$ To regain his former profit position the supplier's obvious first step would appear to be withdrawal of the competitive allowances; but unless other suppliers were to do the same, such a course of action would only place his dealers at the same competitive disadvantage as before. Yet the allowances were withdrawn in the case study. ${ }^{64}$ The fact is that all the suppliers decided to stop subsidizing their retailers at the same time. Conscious collusion among suppliers is not necessary to obtain this result. The explanation lies rather in a deep-rooted characteristic of the gasoline industry-price leadership. ${ }^{65}$

he was Secretary of the Interior, before the American Petroleum Institute in Dallas, Texas, on November 14, 1934, reprinted in TNEC Monograph 39A, 94-95 (1941).

58. "Normal" as used here means the price which was being charged before the price cutting began.

59. United States v. Colgate and Co., 250 U.S. 300 (1919). For possible violations of $\$ 5$ of the Federal Trade Commission Act, see FTC v. Beech-Nut Packing Co., 257 U.S. 441 (1922).

60. Cf. Miles Medical Co. v. Park and Sons Co., 220 U.S. 373 (1911).

61. 50 StaT. 693 (1937), 15 U.S.C. \$1 (Supp. 1951).

62. In addition the supplier itself can sometimes "hold the dike" by maintaining the price at a company-owned station located on the perimeter of the affected area.

63. Although cheaper gasoline might encourage people to use their cars more, it is not believed that this will cause any great increase in over-all consumption.

64. Removal of subsidies by suppliers will not stop the price war. However, it will lessen the severity of the war.

65. For an excellent economic study of price leadership in the gasoline industry see Dirlam and Kahn, Leadership and Conflict in the Pricing of Gasoline, 61 YALE L.J. 818 (1952). See also Learned, Pricing of Gasoline: $A$ Case Study, 26 Harv. Bus. Rev. 723 (1948); Lynch, The Concentration of Economic Power 174 (1946). 
In "normal" times the tank wagon price in the gasoline industry remains stable through a system of price leadership. A single marketer, usually the largest in a given area, quotes a price for his product which is usually followed by other marketers in the area. ${ }^{66}$ No agreement or understanding ${ }^{67}$ is necessary. The suppliers justify this practice ${ }^{68}$ by reasoning that since the price leader is studying conditions of supply and demand it will know when the time is ripe for a price change. The fact that sometimes the leader is not followed in a price rise would indicate that this is a flexible practice and that other suppliers are also studying economic conditions attendant to determining prices. Inevitably a leader is followed down because it has the largest number of outlets in the area, and failure to drop price would undoubtedly cause a tremendous loss of gallonage. ${ }^{69}$

66. "Thus the leader almost always is one of the great integrated companies and more often than not a member of the original Standard Oil group. Table 18 lists the market leaders for various areas in 1939.

\section{"Tarle 18. Market Leadership in the Petroleun} INDUSTRY, 1939.

\section{Area}

New York and New England

Pennsylvania and Delaware

New Jersey, Maryland, Dist.

of Columbia, Virginia, North

Carolina and South Carolina

Ohio

Kentucky, Mississippi, Alabama,

Georgia and Florida

Tennessee, Louisiana and

Arkansas

Michigan, Indiana, Wisconsin,

Illinois, Iowa, Missouri, North

Dakota, South Dakota, Nebraska,

Kansas and Minnesota

Montana, Wyoming, Colorado, New

Mexico, Idaho and Utah

Washington, Oregon, California,

Nevada and Arizona

Oklahoma

Texas

Source: Hearings before the Temporary National Economic Committee, Part 16, 8880-8881." LYNCB, op. cit. supra note 65, at 177.

67. "The fixing of prices by one member of a group pursuant to express delegation, acquiescence, or understanding is just as illegal as the fixing of prices by direct joint action." U.S. v. Masonite Corp., 316 U.S. 265, 276 (1942).

68. The practice was explained before the TNEC by Mr. Sidney A. Swensrud, Vice President of the Standard Oil Co. of Ohio. See Cook, Control of THE Petroleum Industry 47-49 (TNEC Monograph 39, 1941).

69. An ancillary type of price leadership occurs in setting the service station (retail) price where the supplier-owned-and-operated stations set a price which is usually followed in the area by independent retailers of the same brand. Such a price leader can also come from the ranks of the owner or lessee retailers. In the past, associations have been advised by their executives to engage in a system of price leadership. TNEC Hearings, Part 16, 9040-9045 (1940). 
Since price leadership ${ }^{70}$ deals with a national economic concentration of power against which the antitrust laws may or may not be aimed, ${ }^{71}$ it relates to too broad a topic for this Note, which deals with a local economic problem-a price war. ${ }^{72}$ However, one aspect of price leadership will be treated at this point: the uniformity with which competitive allowances were withdrawn in the price war under consideration. ${ }^{73}$ Although it is un-

70. Price leadership in itself has never been condemned by the courts as a violation of the antitrust laws. In at least two cases price leadership was introduced as evidence of the existence of a monopoly and in both cases the fact of the leadership was considered insignificant. See United States v. U.S. Steel Corp., 251 U.S. 417 (1920) and United States v. International Harvester Co., 274 U.S. 693 (1927). "And the fact that competitors may see proper, in the exercise of their own judgment, to follow the prices of another manufacturer, does not establish any suppression of competition or show any sinister domination. [Citing U.S. Steel Case]" United States v. International Harvester Co., supra, at 708, 709.

71. It has been argued that since price leadership brings about the same conditions as price fixing, i.e., inflexible markets, continuance in business of high cost producers, and production not in accord with present demand, it should be condemned. Handler, A Study of the Construction and ENForcenent of THE Federal ANTItrust Laws 41 (TNEC Monograph 38, 1941). In order to combat the evils of price leadership, Handler suggests in this article as a possible remedy the creation of a flexible administrative agency to investigate industries where price leadership is prevalent, "to eliminate the causes of conditions favorable to the practice, and to restore, invigorate, and protect competition in such industries." Such a program to be carried out successfully would entail an agency with large investigative, remedial powers because of the variety of factors to be considered in each case. The government agency might preclude disastrous price wars by its method of stopping price leadership. However, business which now feels that its hands are tied too strongly by the strings of agency control would very likely oppose another extension of bureaucracy into its domain. Although this argument has merit, it is the public interest which is paramount, and if the stratifying effects of price leadership can only be met by an expert governmental agency, then such regulation should obtain. Utilization of traditional remedies would appear to be either too drastic or wholly or partially ineffective. A new approach to the problem is needed. A flexible agency unconfined by the rigors of judicial process might be the answer.

72. Since price leadership can only be maintained by a relatively large and powerful firm, it would appear that it is one of the manifestations of "bigness." Some authorities have advocated a return to the more classical concepts of competition, as opposed to oligopolistic competition, by means of judicial surgery. Professor Eugene V. Rostow has been a leading proponent of such a solution. See, among his other writings, A NATIONAL POLICY FOR THE OII INDUSTRY (1948); Monopoly Under the Sherman Act: Power or Purpose?, 43 IL. I. REv. 745 (1949); Entry Into the Oil Refining Business: Vertical Integration Re-examined, 61 YALE L.J. 856 (1952).

On the other hand it has been pointed out that courts, with so much authority to the contrary, would probably not now attack "bigness," since divestiture in all oligopolistic industries would logically follow, and the ensuing decentralization of power would seriously impair the nation's defense efforts. See, generally, Johnston and Stevens, Monopoly or Monopolization-A Reply to Professor Rostow, 44 ILL. L. REv. 269 (1949) ; United States v. Aluminum Co. of America, 91 F. Supp. 333, 347 (S.D.N.Y. 1950). Possibly the court's position with respect to "bigness" might be modified in the near future. Two pending cases will at any rate give the court the opportunity: the currently pending duPont case, and United States v. Standard Oil of California, Civil No. 11584-c, S.D. Cal., May 12, 1950.

73. The Camden-Philadelphia area presents a very interesting situation because each city is in the "territory" of a different price leader, and a price war in one city will be felt in the other. (The present tankwagon price in Camden is 14.6 cents plus tax and in Philadelphia, 14.7 cents plus tax). The fact that the competitive allowances were removed almost simultaneously in both areas, each area having a different price leader, should at least stir the imagination of some antitrust prosecutor. 
known who supplied the initial spark to bring about this result, no doubt one of the purposes of the policy decision to cease subsidizing was a desire to stop further "spoiling of the market." This conscious parallel action ${ }^{74}$ on the part of suppliers would seem to fall within the doctrine enunciated in Interstate Circuit, Inc. v. United States, ${ }^{75}$ in that the competing suppliers appeared to have accepted an "invitation to participate in a plan, the necessary consequence of which if carried out, [would be] a restraint of interstate commerce." 76 This would be sufficient to establish an unlawful conspiracy. ${ }^{77}$ However, a holding that such tenuous evidence of conspiracy is capable of proving conclusively an illegal restraint of trade would be manifestly unfair to business interests. Here a standard ${ }^{78}$ commodity is being sold. Composition and processing of gasoline is practically uniform. The over-all market demand is inelastic and the number of competitors relatively small. ${ }^{79}$ A uniform price is therefore not surprising. Furthermore, from the very outset, the allowances in the case studied were considered temporary. Because good business reasons ${ }^{80}$ may exist in this concert of action which are compatible with maintaining an "effective" 81 competition, it would appear that the doctrine of conscious parallelism should be used as a procedural device which would direct the burden of proof. ${ }^{82}$ The uni-

74. For an analysis of the evolutions of the conscious parallel action doctrine see Kittelle and Lamb, The Implied Conspiracy Doctrine and Delivered Pricing, 15 Law \& Contemr. Prob. 227 (1950); Note, Conscions Parallelism-Fact or Fancy?, 3 Stan. L. Rev. 679 (1951).

75. 306 U.S. 208 (1939).

76. $I d$. at 227 . The doctrine has since found application in a number of privately prosecuted motion picture distributing cases and also in cases instituted by the FTC. See, e.g., Bigelow v. RKO Radio Pictures, 150 F.2d 877 (7th Cir. 1945), rev'd on other grounds, 327 U.S. 251; William Goldman Theatres, Inc. v. Loew's Inc., 150 F.2d 738 (3d Cir. 1945). In Triangle Conduit Cable Co. v. FTC, 168 F.2d 175 (7th Cir. 1948), aff'd per curiam sub nom. Clayton Mark and Co. v. FTC, 336 U.S. 956 (1949), the doctrine was further extended when proof of use in the industry of a delivered price method, common knowledge of such use by competitors, and substantial uniformity of published prices was enough to establish an unfair method of competition.

77. But cf. Pevely Diary Co. v. United States, 178 F.2d 363 (8th Cir. 1949), cert. denied, 339 U.S. 942 (1950) (price uniformity held insufficient to prove conspiracy where costs of products standardized and no other evidence).

78. The nationally advertised brands of gasoline have about equal consumer acceptance, which would indicate that different additives used by the major companies produce no marked difference in the performance of the product.

79. "The number of major oil companies operating in the different states ranges from 5 to 16 , the modal number being $11 . "$ Cook, $o p$. cit. supra note 68 , at 41 .

80. "No parallelism, conscious or unconscious, can overcome a finding of reasonableness." Fanchon and Marco v. Paramount Pictures, Inc., 100 F. Supp. 84, 104 (S.D. Cal. 1951).

81. In recent years, many authorities have chosen to discuss competition in terms of effectiveness or workability. See, e.g., Adelman, Effective Competition and the Antitrust Laws, 61 HARv. L. REv. 1289 (1948); Oppenheim, Federal Antitrust Legislation: Guideposts to a Revised National Antitrust Policy, 50 Mrch. L. Rev. 1139 (1952) ; Smith, Effective Competition: Hypothesis for Modernizing the Antitrust Laws, 26 N.Y.U.L. REv. 405 (1951).

82. Handler, A Study of the Construction and Enforcenent of the Federal Antitrust Laws 41 (TNEC Monograph 38, 1941). 
formity of action should give rise to a prima facie collusive understanding. It would then be up to the defendant, who has more access to the facts, to come forward to rebut the presumption of illegality. ${ }^{83}$

If the suppliers in the instant situation cannot carry the burden of showing that the uniform cessation of subsidy practices was reasonable, the government is faced with the further problem of what relief to seek. ${ }^{84}$ The damage has been already done. Of course, if the concert of action applies to future policy an injunction could handle the matter by directing that the companies not be guided in its subsidy practices by any "agreement" not to subsidize. But at present suppliers are already very reluctant to grant subsidies. Thus proof of a future agreement to the same effect would be difficult.

\section{Prevention of Price Wars}

Limitation of Sign Sizes.-One attempt to mitigate retail price competition in the Philadelphia-Camden area has taken the form of legislation which limits the size of price signs on the station premises. ${ }^{85}$ The main promotional weapon of the price-cutter is his large sign announcing his price to those in its vicinity. It is generally felt in the industry that this type of legislation has considerably stabilized prices in areas where it has been enforced. ${ }^{85 a}$ But its constitutionality has been contested successfully in various states. ${ }^{86}$ Its proponents have argued that "circus signs" cause accidents by distracting the attention of motorists; ${ }^{87}$ that large signs lead

83. Handler, Anti-tmust-New Frontiers and New Perplexities, 6 RECORD oF THE Assoctation of THE Bar of THE City of New YoRk 59, 67 (1951). The shift in the burden of proof would not be inconsistent with antitrust policies as they have developed in recent years. See, e.g., Providence Fruit and Produce Bldg., Inc. v. Gamco, Inc., 194 F.2d 484 (1st Cir. 1952), where the court put the burden on defendant to show the reasonableness of its practice in excluding plaintiff from facilities of defendant organization.

84. "In any equity suit, the end to be served is not punishment of past transgressions, nor is it merely to end specific illegal practices. A public interest served by such civil suits is that they effectively pry open to competition a market that has been closed by defendants' illegal restraints. If this decree accomplishes less than that, the Government has won a lawsuit and lost a cause." International Salt Co. v. U.S., 332 U.S. 392, 401 (1947). See Schwartz, FreE ENTERPRISE AND ECONOAITC ORGANIZATION 519 (1952).

85. PA. Stat. Ans. tit. 72, $\$ 2611 \mathrm{y}$ (Purdon Supp. 1951) prohibits price signs which are higher or wider than twelve inches. See also the New Jersey statute, note 15 , supra.

85a. These sentiments were recently reiterated when various dealers were asked to comment on a court ruling declaring sign size statutes unconstitutional. The Philadelphia Evening Bulletin, Feb. 27, 1953, p. 3, col. 3.

86. State v. Hobson, 83 A.2d 846 (Del. Sup. Ct. 1951) ; Levy v. City of Pontiac, 331 Mich. 100, 49 N.W.2d 80 (1951) ; State v. Miller, 126 Conn. 373, 12 A.2d 192 (1940) ; Regal Oil Co. v. State, 123 N.J.L. 456, 10 A.2d 495 (1939) ; Commonwealth v. Vaughn, Pa. Ct. of Quarter Sessions of Beaver County, July 24, 1952; Gambone v. Commonwealth, Pa. Court of Common Pleas of Dauphin County, Feb. 25, 1953. Contra: Merit Oil Co. v. Director of Division of Necessaries of Iife, 319 Mass. 301, 65 N.E.2d 529 (1946) ; People v. Arlen Service Station, 284 N.Y. 340, 31 N.E.2d 184 (1940) ; Mark Robbins v. City of Philadelphia, Pa. C.P. 6, March 1, 1951.

87. ". . . these big signs have a habit of having people drive in and clogging up the roadway . . ."; "... if a motorist is proceeding along the highway and 
to price wars which incite violence among dealers; 88 that dealers are forced by price wars to cheat the public in order to stay in business; that price wars lower the morale of the dealers $;^{89}$ and that consequent emphasis on gallonage deprives the public of customary service and courtesy. ${ }^{90}$ On the other hand, opponents of the legislation urge that highway accidents are more likely to occur if a price conscious motorist must slow down in order to see a small sign; that there is little evidence that price wars have incited violence among dealers; that breaches of the peace and dealer cheating should be punished and deterred by existing statutory and common law and not by an indirect method which stultifies competition; that dealer morale should not be promoted by depriving the public of the advantage of competitive prices; and that there is nothing to prevent any dealer from offering services and charging more for gasoline. It would appear that the motive behind this legislation was to insulate the less efficient, higher cost, and lower volume dealers from competition. The expense of this protection ultimately falls on the consuming public which is denied the advantage of price competition. It is submitted that there is nothing which should render gasoline dealers any more immune from competition than other merchants. These statutes appear to be an arbitrary attempt, under the guise of police regulation, to eliminate competition by forbidding any effective advertisement of prices. ${ }^{91}$

Prohibition of Self-Service Stations.-Another attempt to lessen competition among retail dealers of gasoline has taken the form of a New Jersey statute prohibiting the operation of gasoline stations on the self-service principle.92 In upholding this statute, the New Jersey Supreme Court noted that the professed legislative purpose is that of protecting the public against an increase in fire hazard attending this form of gasoline distribu-

sees this rather large sign ... he is apt to take his eyes off the road... and create traffic problems. . " Transcript of Record, pp. 22 and 25 , Mark Robbins v. City of Philadelphia, Pa. C.P. 6, March 1, 1951.

88. "Gradually that condition grows worse ... until it gets into a gigantic gas war, when dealers all over ... who wanted to stay in business . . . had to sit in their ... stations with shot guns on their laps in order to protect themselves from violence. . . ." Id. at 47.

89. ". . . it puts the retail gasoline business on a rather low plane, where men can advertise like that. . . . It sort of broke the industry down to a grease ball business instead of . . . a businessman's business." Id. at 32.

90. "On the other hand, you have [those] who want to have ... a couple of .. . pumps ... out front, with the chair not too far away where they can go out, pick it up, squirt it in, put the money in their pocket, and go back and sit in the chair." Id. at 65 .

91. See note 86 supra. Cf. Williams v. Standard Oil Co., 278 U.S. 235 (1929) (the Court held there could be no price regulation of gasoline because it is not "affected with a public interest") ; Jay Burns Baking Co. v. Bryan, 264 U.S. 504 (1923) (the Court said that it is beyond the power of a state, under the guise of protecting the public, to impose unreasonable and unnecessary restrictions upon bakers).

92. N.J. Stat. Ann. tit. 34, c. 3a, $\$ 1$ (Supp. 1952) : "It shall be unlawful for an owner ... of any retail ... service station... to permit any ... customer ... to use or manipulate any pump ... or other device for ... dispensing gasoline ... for the purpose of filling the tank of a motor vehicle. . . ." 
tion. ${ }^{93}$ But, in California, where such stations are widespread, both casualty and fire insurance companies maintain the same or even lower rates for supervised self-service stations as for conventional stations. ${ }^{94}$ Stripped of its purported public safety purposes, it would seem that such a statute is merely another device to mitigate price competition at the retail level of the industry. ${ }^{95}$

Resale Price Maintenance.-An exception to the general prohibition against price fixing agreements is contained in the state fair trade laws. These laws authorize manufacturers, producers or distributors to enter into contracts with wholesalers or retailers for the purpose of fixing minimum prices for the resale of branded goods in intrastate commerce. ${ }^{96}$. All contain provisions that non-signers, having knowledge of the existence of such contracts, are bound to the same extent as the contracting parties. The Miller-Tydings amendment to the Sherman Act validated for the purposes of interstate commerce all "contracts and agreements" entered into pursuant to state fair trade acts.97 In 1951, the Supreme Court held that this amendment did not validate the non-signer provisions of these statutes. $^{98}$ A strong desire to avoid any practice which has the semblance of an anti-trust violation has led the major suppliers in the past to shun the use of this means of resale price maintenance. In addition, some retail dealers display a surprising reluctance to having their prices dictated in this fashion. Therefore, this. method of softening competition has had little significance in the gasoline industry. A recent amendment to the Federal Fair Trade Law, however, sanctions for the purpose of interstate commerce the nonsigner provisions of the state fair trade laws. ${ }^{99}$ This could be a powerful weapon in the hands of the major refiners. But the interests of the gasoline consumer would be better served if it were not used, since, by eliminating price competition among dealers with different levels of costs, it prevents price reductions which could and should be made. Legislation recognizing fair trade prices is an invitation to maintain the status quo. Such price fixing rewards a minority group by sacrificing the interest of the majority. ${ }^{100}$

Minimum Dealers Margins.-Unfair sales laws have been enacted in thirty-eight states. Like the resale price maintenance statutes they have

93. Reingold v. Harper, 6 N.J. 182, 192, 78 A.2d 54, 59 (1951).

94. 99 U. OF PA. L. REv. 1016, 1017 (1951).

95. "Price control through the legislative process has long had favor among the operators of gasoline filling stations. . . . The law before us had such sponsorship ... although the advocacy was professed to be grounded in considerations of safety related to the hazards of explosion and fire." Reingold v. Harper, 6 N.J. $182,192,78$ A.2d 54,59 (1951). For a discussion of the constitutionality of the New Jersey Statute, see 99 U. of PA. L. REv. 1016 (1951).

96. E.g., PA. Stat. Ann. tit. 73, \$7 (Purdon Supp. 1951).

97. 50 Stat. 693 (1937), 15 U.S.C. $\$ 1$ (Supp. 1951).

98. Schwegman Bros. v. Calvert Distillers Corp., 341 U.S. 384 (1951).

99. See Pub. L. No. 542, 82d Cong., 2d Sess. §5(a) (1) et seq. (July 14, 1952).

100. In Liquor Store Inc. v. Continental Distilling Corp., 40 So.2d 371 (Fla. 1949), the court held a fair trade statute to be unconstitutional on the ground that it served a private rather than a public purpose. 
been enacted for the declared purpose of preventing abuses of price competition. ${ }^{101}$ But, unlike the fair trade laws, they do not depend for their effectiveness upon the initiative of distributors who, under the fair trade laws, must first set the resale prices for their products. In general, unfair sales laws declare sales of merchandise by wholesalers and retailers at prices less than "cost" to be unlawful when made with intent to injure competitors or to destroy competition. ${ }^{102}$ The difficulties inherent in defining and ascertaining "cost", however, have greatly diminished the effectiveness of this legislation. ${ }^{103}$ Accountants themselves differ widely as to proper methods of assigning general expenses to particular products and periods, and computing other elements of "cost". 104 Problems may even arise in determining the invoice cost for a particular sale. Especially during a price war, when his supplier's price has varied with the competition, the invoice cost to the dealer of a gallon of gasoline is extremely difficult to ascertain. In addition, an exception is contained in many of the acts exempting sales made in good faith to meet competition. While this does not protect an initial price-cutter, this exception withdraws those who follow from the prohibition of these acts. ${ }^{105}$ Moreover, these laws leave untouched the low cost non-branded, and efficient branded, dealers who are primarily responsible for the initiation of price wars. The granting of temporary price reductions by suppliers then permits higher cost retailers to engage in a price war without selling below "cost." 108 For these reasons, this type of legislation has had no apparent effect in mitigating price competition at the level of the gasoline retail dealer.

It has been suggested that legislation directed to the fixing of minimum dealer's margins by a state agency or private cost surveys be enacted. ${ }^{107}$ This contemplates amendments to the present unfair sales laws which would redefine "cost" to include invoice price plus a minimum percentage margin. Such legislation is clearly opposed to the interest of the public in lower prices. In addition to being subject to the infirmities of the existing unfair sales laws, it would harm those dealers who, believing that they can do business more efficiently than their competitors, choose to pass the savings along to their customers.

101. See Rodgers, Unfair Sales Lazes, 38 A.B.A.J. 921, 922 (1952).

102. E.g., Pa. Stat. Ann. tit. 73, §213 (Purdon Supp. 1951).

103. See Cover, Governinent Regutatton as a Factor in Business Mortality 139, 149 (TNEC Monograph 17, 1941).

104. See Comment, 57 YaIE L.J. 391, 395 (1948).

105. But often one who relies on this excuse for price reductions must take the risk that his competitor's prices are themselves in violation of law. See Comment, 57 YALE L.J. 391, 415 (1948).

106. An example of how the enforcement of these statutes may run afoul of the Sherman Act is provided by United States v. Conn. Food Council, Civil No. 680, D. Conn., Nov. 5, 1941. The Connecticut statute required a fixed mark-up unless the seller proved a lower cost. The decree dissolved the Council and enjoined it from threatening litigation, suggesting minimum prices, and computing "an average ... cost of doing business . . . or establishing standards or methods for such computation."

107. Report of the Governor's Conmmittee to Investigate the Gasoline Price WAR 3 (Conn. 1950). 
Agency Control.--Some dealers have suggested, as an alternative to what they consider "destructive competition", the creation of a public agency with authority to control all aspects of the retail level of the industry -including entry, the setting of retail prices, and the determination of permissible methods of advertising. But, in addition to being subject to the same objectionable features as the aforementioned statutes, such an agency would probably be condemned by the courts on the authority of Williams v. Standard $O i l^{108}$ where an agency of much more limited power was struck down by the Supreme Court. The Court held that the ultimate purpose of the agency was to control the retail price of gasoline, which could not be done since the selling of gasoline is not a business affected with the "public interest." 109

\section{ConCLUSION}

The retail dealers of gasoline are in an unenviable economic position. They have been marketing a product at prices which, even before the recent price wars, had risen much less than the prices of comparable commodities. ${ }^{110}$ Many of them, despairing of unrestricted competition, have turned to the legislatures for protection. However, such an approach appears undesirable for the following reasons:

1. Statutes proscribing below-cost sales present a multitude of enforcement problems and become ineffective when the industry engages in subsidy practices.

2. Any legislation fixing retail margins of gasoline by public agencies or private cost surveys would tend to interfere with the correctives of free competition.

3. Legislation allowing resale price maintenance deprives the efficient retailers of the opportunity to pass cost savings on to consumers.

4. Legislation regulating the maximum size of signs displayed at service stations and prohibiting the operation of self-service stations deprives the public of the advantage of price competition in the sale of gasoline. In addition, the constitutionality of such statutes is questionable because their main purpose is price maintenance.

5. A commission set up to regulate trade practices in gasoline retailing with special reference to price wars suffers from the same infirmities as any direct legislation in'this area. State fair trade agencies and criminal statutes can be utilized to deter fraudulent practices.

The public benefits through lower prices. Vigorous price competition helps to eliminate the inefficient retailer, puts increased pressure on sup-

108. 278 U.S. 235 (1929).

109. Accord, New State Ice Cò. v. Liebmann, 285 U.S. 262 (1932) (ice); State v. Harris, 216 N.C. 746, 6 S.E.2d 854 (1940) (dry cleaning). But cf. Nebbia v. New York, 291 U..S. 502 (1934) (milk).

110. Rep. Gasoline Study Comm. of N.J. (1951). 